\title{
The Effect of Yields on Picking Efficiency in Coffee Production ${ }^{1}$
}

\author{
Servando Silva, Fernando Abruña, and José Vicente-Chandler ${ }^{2}$
}

\section{INTRODUCTION}

Picking is the most expensive operation in coffee production. Although it is generally assumed that picking efficiency increases with yields, the authors have found no experimental evidence in the literature to sustain such an assumption.

The present study was conducted to obtain information on the effect of yields on efficiency of picking coffee, using plots with a wide range of productivity from a fertilizer experiment reported on in detail by Abruña, Vicente, and Silva $(1) .^{3}$

\section{MATERIALS AND METHODS}

The test was conducted on steep (45-percent) slopes in the Coffee Region of Puerto Rico. Four-year-old trees of the Bourbon variety of Arabica coffee planted 3 feet apart in rows so as to form hedges were used (fig. 1). Data were obtained from 128 plots of 12 trees each. In general, the plots differed only in such factors as vegetative growth, number of berries per cluster, etc., which naturally vary with yield.

The plantation was harvested five times at 3-week intervals and only ripe berries were picked. Each time the weight of berries harvested from each plot and the time required were recorded. Data from all pickings were then totalled by plots, and efficiency of picking was expressed as pounds of berries picked per man-hour. Total yields of market coffee were calculated, assuming that 5 pounds of berries yield 1 pound of market coffee.

\section{RESULTS AND DISCUSSION}

Yields from the different plots varied from about 100 to 2,500 pounds of market coffee per acre, representing the full range normally expected in coffee plantings.

1 This work was carried out cooperatively between the U.S. Department of Agriculture and the Agricultural Experiment Station of the University of Puerto Rico, Río Piedras, P. R. Special appreciation is due Dr. B. G. Capó, Associate Director. Agricultural Experiment Station, University of Puerto Rico, for statistical analysis of the data.

2 Physical Science Technician, Soil Scientist, and Project Supervisor, respectively, Soil and Water Conservation Research Division, Agricultural Research Service, U. S. Department of Agriculture, st ationed at Río Piedras, P. R.

${ }^{3}$ Italic numbers in parentheses refer to Literature Cited, p. 175. 


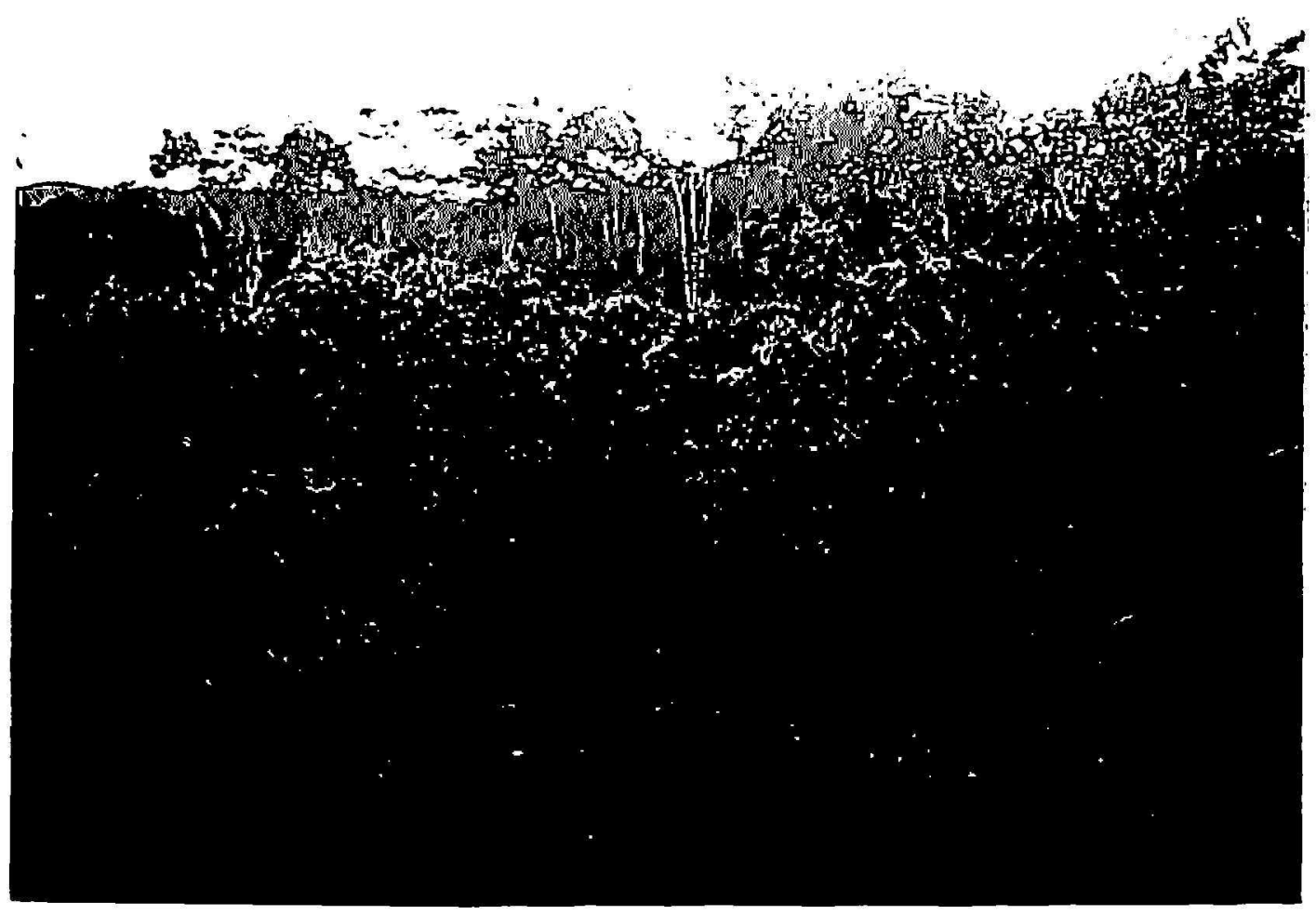

Fra. 1.-View of experimental plots showing extremes in productivity. Plot on left yielded over 2,000 pounds of market coffee per acre, compared to about 200 pounds produced by unfertilized plot on the right.

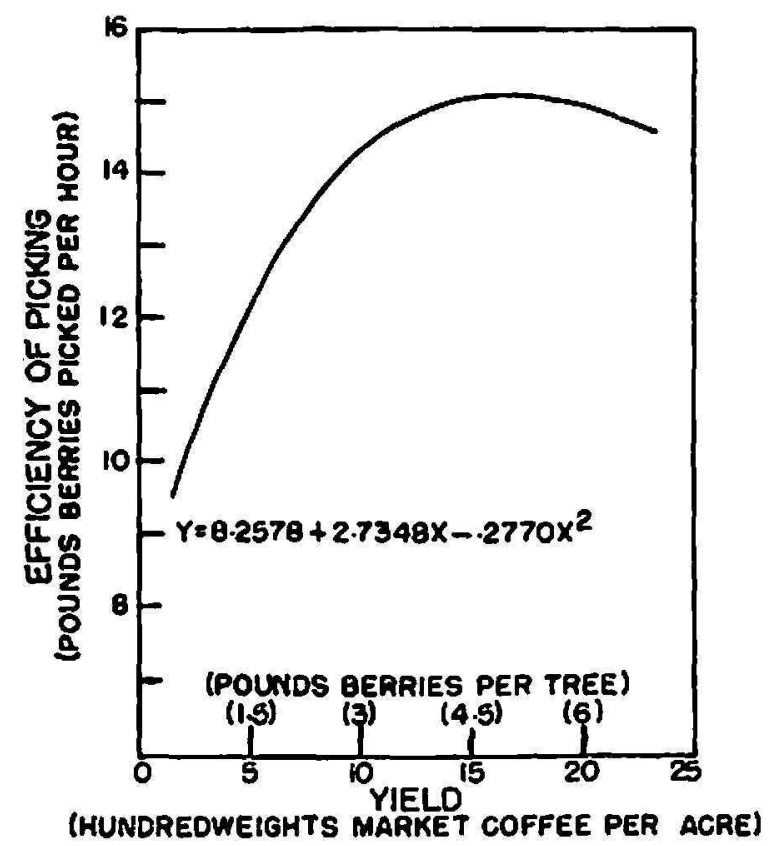

FIG. 2.-The effect of yield on efficiency in picking coffee. 
The statistically highly significant relationship shown in figure 2 explains 38 percent of the total variation and indicates that picking efficiency increased gradually with yields up to about the 1,800-pound level. About 25percent less labor would be required per unit of yield with an 1,800- than with a 500-pound crop.

As yields increase the berries are concentrated on a smaller area and less movement is recuired in picking, resulting in increased efficiency, particularly over the lower yield range. On the other hand, at high yield levels, vegetative growth is naturally more luxuriant and it is more difficult for the laborer to reach the berries. Of more importance, the number of berries per cluster increases rapidly and, since care must be taken to pick only the ripe ones without knocking off the green berries, the work is retarded. For these reasons picking efficiency tends to level-off, or may even decrease slightly at high-yield levels.

It should be pointed out that overall picking efficiency in this study was only about two-thirds of that normally attained in commercial plantings of comparable productivity. This was because extreme care has to be exercised in harvesting experimental plots used for fertilizer experiments. However, there is every reason to believe that the general relationship between yields and picking efficiency would hold true under farm conditions.

The large, overall variability was due primarily to individual differences among the laborers. Time of day and changes in the weather also probably resulted in considerable variation. It should also be noted that almost the entire crop of some of the low-yielding plots was harvested at one picking, resulting in a relatively high picking efficiency although total yields were low.

\section{SUMMARY}

Picking efficiency was found to increase gradually with yields of coffee up to about 1,800 pounds of market coffee per acre in 128 plots varying widely in productivity as a result of differential fertilization.

\section{RESUMEN}

La eficiencia en la recolección de café aumentó gradualmente según aumentaban los rendimientos hasta aproximadamente 1,800 libras de café pilado por cuerda, en 128 parcelas experimentales que variaban grandemente entre sí en producción, como resultado de diferentes aplicaciones de abono.

\section{LITERATURE CITED}

1. Abruña, F., Vicente-Chandler, J., and Silva, S., The effect of different fertility levels on yields of intensively managed coffee in Puerto Rico, J.Agr. Univ. P.R. 43 (3) 141-6, 1959. 